\title{
Sociological aspects of the transformation of agrarian structure of Serbia in 1990-2018*
}

\author{
S. Šljukić, M. Šljukić \\ University of Novi Sad \\ Dr. Zorana Đinđića, 2, Novi Sad, Serbia, 21000
}

\begin{abstract}
One of the constitutive elements of former socialist societies that suffered radical transformations in recent decades of 'the transition' is certainly the agrarian structure. The authors focus on the sociological aspects of the Serbian agrarian structure transformation from the breakdown of the socialist system to the present day. The first phase of changes (1990-2000) created an environment and prerequisites for the differentiation of peasantry that continues until the present day. The second phase (2001 - 2012) is characterized by the appearance of large agricultural enterprises that emerged primarily as a result of privatization. During the third phase (2013-) Serbia has been drawn into the global process of 'land grabbing'. The authors argue that in agriculture, instead of the middle class consisting of farmers, the country got a very differentiated peasantry opposing the large enterprises; and this situation is typical for post-socialist states due to three interrelated reasons: the new social-economic order was not built on the ruins of socialism but rather from the ruins; different actors within the Serbian society pursued their particular interests in the process of changes and followed demagogical declarative instructions from external experts, especially from the West; new political elites did not strive to build ex-socialist states according to their own model but rather met the needs and carried out the plans of their governments and companies, i.e. the term 'periferization' should be used instead of the term 'transition'. In the final part of the paper, the authors try to answer the question why the transitional expectations regarding agrarian structural transformation did not come true, and the institutional framework for the majority of farmers working on the medium-size lands was not created. The authors also try to predict the upcoming possible alterations within the agrarian structure of the Republic of Serbia.
\end{abstract}

Key words: agrarian structure; large farmlands; land grabbing; Serbia; peasantry; farmers; transition

There is no doubt that societies of Central and Eastern Europe have undergone serious transformations over the last three decades. Substantial changes took place in politics, economy and the way of life (culture). It would be very difficult to find a single element of society that has not been significantly altered. Initially this process was called 'transition' to reflect a fundamental change from the one-party system to the liberal-democratic political system, from the administrative planned economy to the free market economy based on private property. etc. Finally, the transition was to ensure a complete harmony between societies of Central and Eastern Europe and societies of the West, thus, providing more freedoms, comprehensive social development, etc. However, it soon became obvious that the transition could not fulfill its promises: for instance, societies of Central and Eastern Europe have not become copies of the Western

* (C) S. Šljukić, M. Šljukić, 2019.

The article was submitted on 31.01.2019. 
European societies, which spawned debates on the definitions of transition claiming that it was not a universal path intended for all, and which changed interpretations of the above mentioned processes to the 'recombinant property' [24] and even 'periferization' [10].

A typical example of the failure of the transformations to achieve the predicted results is agriculture ot rather agrarian structure. Despite the forecast that socialist agriculture will be substituted by small farmers, the expectations regarding the development of family farming were not met. In other words, the agrarian structure created by the transition is not similar the one we see in West European countries due to the fact that large farms (agricultural enterprises) kept their huge share in agricultural production in the countries of Central and Eastern Europe [23]. We will try to explain the transformation of the agrarian structure in Serbia focusing on its sociological aspects in the period from 1990 to 2018 . By the term 'sociological aspects' we refer primarily to the social-structural dimension of changes. 1990 was the year when the new Constitution of the Republic of Serbia was ratified; 2018 refers to the moment when Serbia definitely entered the trend described in the literature as 'land grabbing'. Transformation of the agrarian structure in Serbia consists of three phases: in the first phase (1990 2000), there were some crucial changes that started the process of differentiation among agricultural producers; in the second phase (2001-2012), the formation of large farmlands was completed; in the third phase (2013-), foreign corporate and other capital turned its attention to Serbian farmlands.

We will start with a short review of the situation in Yugoslavia. Although the socialist regime had the same essential characteristics everywhere, there were particular specifities varying from one country to another, which affected the course of transition after the breakdown of socialism. One of the peculiarities of the Serbian (Yugoslavian) society was its agriculture. By the II World War Serbia was a part of Yugoslavia and a predominantly agrarian country. Its agrarian structure consisited mainly of small peasant economies with some number of larger private enterprises in the north. After the World War II, as in several countries of Central and Eastern Europe, the agrarian reforms (1945) began: they atomized farmlands even further, thus, providing opportunities for creating huge state agricultural enterprises. The number of economies ranging from 2 to $10 \mathrm{hec}-$ tares increased and the number of ecomies larger than 10 hectares decreased.

And again, as in other socialist states, the political elite tried to collectivize agriculture so as to control food production. This process was very slow in the first years after the war but accelerated after the geopolitical turn of 1948 (break with the USSR and convergence with the West). In two to three years a tremendous part of agriculture in Yugoslavia was collectivized - the peasantry was forced to join the so called 'peasant farming cooperatives' (SRZ) by administrative pressure and strong propaganda so that to create a Yugoslav version of soviet collective farms (kolkhozes) [17]. In a short time period, SRZ proved to be economically inefficient. In 1953, the communist authorities made a substantial change in the approach to the agricultural policy, perhaps, due to the ideological pressure of the West: peasants were allowed to leave SZR, which led to almost complete decollectivization. Most of SZR were dissolved but simultaneously the agrarian maximum (the allowed private land property) was limited to 10 hectares in plains and to 15 - in mountains. Such a measure and other administrative restrictions 
were the essence of the state modernization of peasant householdings. Large state farms remained but peasant croplands represented more than $80 \%$ of all arable land [20].

Thus, Yugoslavia (and Serbia) became an anomaly in the socialist world because their agrarian collectivization failed. Somewhat similar was the case of Poland [6]. From that period and to the crash of socialism, Serbian agriculture was very special due to its dual structure: on the one hand, there coexisted state-owned agricultural enterprises and state-controlled cooperatives abundantly supported by the state (socialist sector); on the other side, there were peasant farms, atomized but numerous and dominant (private sector) considering the whole farmland capacity. Under administrative limitations and without state funding a number of peasant farms managed to be modernized. These peasant economies increased their economic capital and also preserved and enlarged their cultural capital $[20 ; 22]$.

One of the cornerstones of the changes in post-socialist countries (implemented by the state 'from the top') was the transformation of state property into private. It was assumed that private property as the foundation of free market would ensure more efficient resource management (in agriculture too). Agrarian privatization practically meant a large scale agrarian reform consisting of restitution and repartition of large (collectivized) farmlands under the farmers' control. That agrarian reform was realized by ex-socialist states differently and with different outcomes $[7 ; 12 ; 14 ; 23]$. In some countries, for instance in Romania, the results of the agrarian reform were devastating: the farmland was owned by elderly peasants and their heirs who lived in cities, which destroyed agricultural production [21]. Due to the fact that collectivization in Yugoslavia failed in the 1950s and that smallholders owned most farmlands, the agrarian reform in Serbia had significantly less effects as compared to other socialist countries. However, some changes in agriculture can be considered as an agrarian reform for they started transformations of agrarian structure.

Certainly, the most important measure was the abolishment of farmland of maximum of 10 (15 in mountains) hectares that was embedded in the Constitution and that 'medium-sized' the peasantry. This was finally done by the Constitution of 1990. The farmland market that suffered numerous limitations until that moment awakened. Due to the lack of measures concerning property of farmlands, the process of peasant differentiation started. Until this point, smallholdings were 'frozen', so peasants spent money on mechanization, construction and other non-production purposes. The new situation allowed peasants who accumulated some resources (including social and cultural capital) to increase their estates and croplands for market purposes. However, households without young workforce and proper mechanization were forced to sell their lands.

The second measure was a limited restitution of land property: peasants whose land was taken in 1953 received their property back. The same applied to the land confiscated in the period of mandatory purchase of agricultural products (1945-1952). 'The Law on Terms and Conditions for Recognition the Right and Restitution of Land Transferred into State Property According to the Legislature on Agricultural Land Fund and Confiscation due to the Failure to Meet the Set Deadlines of Mandatory Purchase of Agricultural Products' was implemented for a long time and accompanied by numerous problems, mainly due to the fact that the farmlands that were to have been returned to their 
owners were still cultivated by state firms. The most important consequence ensuing this affected new farmlands that were 'thrown' on the market, which started a new spurt of differentiation. The successors who lived in urban areas often did not have any other choice but to sell their recently acquired land. The process of restitution involving recognition and inclusion of the agrarian reform of 1945 started a decade later (2011), and is still ongoing with numerous problems and controversies.

In 1992, a new bill was passed to separate collective and state farmlands. 'Social property' was one of the specifities of socialism in Yugoslavia and represented a kind of collective property that was managed by social companies but the final decision was always on the state (social property was a type of state property). Division of agricultural land was the consequence of the state intention to identify farmlands for privatization and to be kept in state property. However, mass privatization did not start until $21^{\text {st }}$ century, before it was quite sporadic. State rejection to privatize social farmlands was determined by the believe of the political elite that mass privatization (of land and other resources) would mean a loss of control over financial flows.

Despite the lack of mass privatization in the 1990s, which meant for Serbia the status of 'blocked transformation' [11], there were significant changes in social structure due to the development of private property almost beyond limits. In agriculture, under the slow, steady and apparent processes of differentiation of peasant smallholdings and concentrated aggregation of farmlands, the average farmland grew from 2,4 hectares in 1991 to 5,44 hectares in 2012 [1] (the methods of measuring the average farmland in 1991 and 1012 were not identical but they are comparable). Consolidation process was accelerated by the market. Farmers with larger reserves of various capital (economic, social and cultural) succeeded in the market, while the other stagnated and/or were thrown out of the market. Considering the fact that the Serbian state does not follow a consistent policy in agriculture we can expect further differentiation of agricultural producers in the future.

Soon after leaving the model of imposing the maximum land size, the market of agricultural land got new managers of socialist firms and businessmen who accumulated their capital in other domains (commerce, banking, industry) and often did not have any relations with agriculture but realized that the new market provided new opportunities to convert their social capital into economic or to simply increase their wealth by safe investments in farmlands. Thus, since the second hals of the 1990s, the process of developing large estates and huge farmlands (contemporary latifundia) started.

We should mention that there have been large farmlands in the northern parts of Serbia (Vojvodina) since the feudal era. The Revolution of 1848 turn these feudal lands into capitalist private property. In 1918 these lands became a part of the Serbian Kingdom, subsequently a part of the Kingdom of Serbs, Croats and Slovenes. Most of the landowners were foreigners - Germans and Hungarians. By the agrarian reform of 1919 these farmlands were confiscated and given to peasants, while owners of large farmlands who were of Serbian nationality kept their (reduced) farmlands. It is interesting that socialism did not abolish large farmlands and only enabled changes of ownership: since 1945, state (later social) agricultural enterprises became proprietaries of thousands of hectares of farmlands, mainly in Vojvodina. These farmlans were even enlarged in the 1960 - 1970s within the process of creating guhe agro-industrial complexes [22]. 
Large estates in Northern Serbia survived in the post-socialist environment, and their consolidation and growth were determined mainly by privatization. After the shift of the regime (2000), new features of the Serbian economy accelerated transformation of social property into private property. In 2001, the 'Law on Privatization' was adopted and approved the sale of social (state) enterprises (including agricultural) via auction or tender. Privatization was implemented by a new state institution - Privatization Agency. Its model led to the aggregation of enormously large farmlands due to the fact that social agricultural enterprises were sold together with agricultural land. The purchase of social agricultural farmland provided buyers with enormous legal privileges. A hectare of farmland in social property cost several times less than the land at free market: about 500 Euros per hectare vs. ten times higher price at the open market. Also the buyer gained the right to freely and without charge use and exploit the state farmland. This privilege was cancelled in 2006 when the state finally decided to charge the rent.

For the first time an agriculture company was privatized in 2002. By 2010 the state sold 179 agricultural economies. 9 agricultural complexes with 7 to 9 thousand hectares were sold by tender. About $80 \%$ of farms were sold cheaper than their actual capital asset value. Two thirds of buyers were the owners of big private companies [15]. There were so few new landlords that they could be counted on the fingers of one hand. There are no reliable data on how much land was owned by each individual but it is estimated to range from 10 to 30 thousands hectares [22]. Some owners had favorable 'starting positions' won in the 1990s, while others began as independent entrepreneurs wioth close relationships with political elites. Their wealth would have been much smaller without their social capital; moreover, they share the common feature of being present in other branches of economy (food industry, commerce, banking, insurance).

Large farmlands are used in a capitalist manner - by hiring workforce from seasonal workers to engineers and managers. The productivity is high due to the mechanization and minimal number of employees. They produce for domestic and foreign markets; tend to invest abroad; purchase agricultural land in other former socialist countries (for example, in Ukraine). These new latifundists consider agricultural land primarily as a commodity that can be bought and sold at will. In other words, these capitalists acquired their wealth recently, they are not members of nobility or peasants (farmers) who inherited their farmland and are strongly tied to land by traditions and not merely economic interest [22].

This period is marked by another important characteristic also related to privatization: due to privatization of industrial complexes and massive cuts in number of employees, the share of workers in industry dropped by $12 \%$ (from 33,5\% in 2001 to $21,6 \%$ in 2009), while the deagrarization trend ceased and even reversed. In the same period there was a $4 \%$-increase in number of employees in agriculture (from $19,6 \%$ to $23,9 \%$ ). It is obvious that the third sector (increase from $46,9 \%$ to $54,5 \%$ ) could not absorb all those who lost their jobs in industry, which made some people return to agriculture on the farmlands of their ancestors. The majority of reagrarizationed former industrial workers own smallholdings and produce enough just to satisfy the needs of their families, i.e. their marginal participants of the market [18].

Over the human history agricultural land represented the paramount resource concerning the life needs. In modern societies, industry became increasingly significant, 
then finance and tiday information. However, under the economic crisis the value of agricultural land grew due to the simple fact that in such times food becomes more important. This is exactly what happened in the late 2000s under the global economic crisis. All of a sudden many powerful economic factors stared to invest in farmlands and strived to purchase or rent as much farmland as possible. Such a chase after agricultural land in recent decades was named 'land grabbing'. Starting from 2008, big companies and governments try to seize control over large agricultural areas all around the world but primarily in the Third World (Africa, Asia and Latin America). By 2012 in developing countries there were 1217 contracts on 83,2 million hectares. The largest investors are China and Chinese companies, then the rich oil countries of the Arabian Peninsula (Saudi Arabia, United Arab Emirates, Qatar and Bahrain) and South Korea. These countries have a permanent problem of ample supply of food due to the natural conditions or overpopulation. Therefore, they try to solve the problem by purchasing agricultural farmland in other countries. Land grabbing affects lives and perspectives of millions of people in developing countries, which determines numerous political conflicts. For instance, when the South-Korean company Daewoo Logistics Corporation tried to rent 1,3 million hectares of Madagascar farmland to set production of corn and palm oil, the political conflict dislodged the government $[3 ; 13]$.

Land grabbing is not confined to developing countries, it is widespread in Eastern Europe and the former USSR states. The above mentioned actors tend to seize large farmlands in Serbia together with western governments and companies, whose activities are usually named 'foreign direct investment' rather than land grabbing. Numerous business contracts transfered hundreds of thousands of farmlands in Romania, Ukraine and other countries into foreign property. The prices of farmland in Eastern Europe are significantly lower than in the West: while on average the price of a hectare of Dutch farmland is 63000 Euros, in Romania it is only 1958; renting a hectare of Dutch farmland costs 791 euros, in Latvia - 46 euros. For the investors from Western Europe the price of Eastern-European farmland is very cheap, while for local investors it is less affordable. The European Union institutions express concerns about land grabbing and suggest restrictions on free capital movement. However, these reductions and limitations are not applied to the EU businessmen [4; 9]. Land grabbing is often justified by positive effects of foreign investments such as new workplaces, increase of export, etc., but the dominant estimate of it is that it brings many problems to local rural population, environmental issues and permanent loss and alienation of national resources $[9 ; 16]$.

Many countries make efforts to legally prevent or limit foreign property in their agriculture. In 2006 Serbia adopted the 'Law on Agricultural Farmlands' which ensured that landowners in Serbia were to be exclusively Serbian but not foreign entrepreneurs and companies. However, foreign companies found a 'loophole', opened firms in Serbia and bought about 22.000 hectares. These companies were from Croatia, Hungary and Ireland [5]. These farmlands were significantly smaller compared to the ones bought by Serbian companies had bought so this foreign ownership (formally Serbian) did not worry anybody. The first symptoms of Serbia being entrapped in land grabbing appeared in 2013 when the Government of the Republic of Serbia signed a contract with the company from the UAE to achieve the takeover of domestic firms that owned more than 10 thousand hectares. This preliminary contract was fiercely opposed by peasant asso- 
ciations and finally the government did not sign it. However, the government did not give up the very idea and signed another contract in 2014 with another company from the UAE [8]. In September 2018, the government sold 'Agricultural complex Belgrade' (that made available almost 17.000 hectares) to Al Dahra Holding for the price twice smaller than the officially estimated one [2].

The next step in favor of foreign investors was made in 2015 when the 'Law on Agricultural Farmlands' was altered allowing a 30\% rent for 30 years in all farm areas of local municipalities for large entrepreneurs via direct bargain. Thus, the German company 'Tönnies rented about 12.000 hectares. In the same year, there were tough debates between Serbia and EU on the legal status of real estate ownership. The Stabilization and Association Agreement between Serbia and EU (article 63, section 2) say that after a four-year period following ratification (completed in 2013) Serbia must change its legislature to make the property rights the same for its citizens and citizens of the EU. This meant that citizens of Serbia and citizens of the EU would have the same right under equal terms and conditions to purchase any farmland in Serbia. Due to the enormous public pressure and scientific and professional arguments the 'Law on Agricultural Farmland' was changed and limited the possibilities of the EU citizens to buy agricultural land. However, concerning the legal capacity of foreigners to buy farmlands via domestic firms, Serbia remains in a very vulnerable position facing the ongoing process of land grabbing.

According to the data of the last census (2012), Serbia has 3861477 hectares of agricultural farmland: $89 \%$ are used; $30 \%$ are rented. There are 631552 registered smallholdings and about 108230 unregistered. From the total number of smallholdings, only $0,5 \%$ is owned by legal entities (entrepreneurs, agricultural cooperatives, etc.), while the rest is owned by familis (peasants, farmers). The average size of farmland in smallholding is 5,4 hectares divided into six parcels with an average size of parcel of 0,98 hectares [1].

Since the times of socialism that 'mediumized' social classes, peasantry became quite differentiated: $47 \%$ of landowners uses up to 2 hectares of agricultural farmland; farmlands larger than 10 hectares represent only $0,82 \%$ but use about $42 \%$ of farmland; holdings with more than 100 hectares represent $0,03 \%$ but use $21 \%$ of farmland [1]. Large croplands are concentrated in the plains of Vojvodina in northern Serbia (farmlands larger than 1000 hectares). Therefore, besides highly differentiated peasantry, in Serbia two other agricultural classes coexist: big landowners (Serbian and foreign) and employees of their farms. Such an agrarian structure developed very early and has not significantly changed.

Transitional expectations of an effective political, ecomic and comprehensive social system did not come true. The changes in economic sphere were reduced to privatization, which led the society to deindustrialization, unemployment and massive debt. In agriculture, instead of the middle class of productive farmers we see differentiated peasantry in opposition to large farmlands (in many post-socialist states). Large estates and vast farmlands were preserved in many regions and expectations of the development of family farming did not come true. Such a result is determined by at least three interconnected causes: first, the ruins of socialist system were not tabula rasa as was declared by neoliberals and Marxists, i.e. the new order was not built on the ruins of socialism 
but rather from the ruins $[24 ; 25]$; second, different actors within Serbian society followed their particular interests and relied on the demagogical declarative statements from outside (from the West); third, the political elite did not strive to build up postsocialist states according to their own model but simply implemented the plans of their governments and business. Therefore, we should use the term 'periferization' instead of the term 'transition' referring to Wallerstein's theory of center and periphery [10]. Thus, we can expect further differentiation of agricultural producers for large farmlands will grow and influence of foreigners will expand in the conditions favorable for land grabbing. Such a polarized agrarian structure with the expanded foreign ownership inevitable leads to social instability.

\section{References}

[1] Agriculture in the Republic of Serbia. Book 1. Beograd; 2013 (In Serbian).

[2] Arabs take over PKB. Telegraf. 14.09.2018 (In Serbian).

[3] Braun von J., Meinzen-Dick R. "Land grabbing" by foreign investors in developing countries: risks and opportunities. 2009. http://www.landcoalition.org/sites/default/files/documents/ resources/ifpri_land_grabbing_apr_09-2.pdf.

[4] Bunkus R., Theesfeld I. Land grabbing in Europe? Socio-cultural externalities of large-scale land acquisitions in East Germany. Land. 2018; 7 (3).

[5] Gulan B. The Fate of Confiscated Property. Novo Miloševo; 2015 (In Serbian).

[6] Halamska M. The evolution of family farms in Poland: Present time and the weight of the past. Eastern European Coutryside. 2016; 22.

[7] Hartvigsen M. Land reform in Eastern and Central Europe after 1989 and its outcome in the form of farm structures and land fragmentation. FAO; 2013. http://www.fao.org/3/a-aq097e.pdf.

[8] Investments in weeds have grown. Vreme. 11.08.2016 (In Serbian).

[9] Kay S., Peuch J., Franco J. Extent of farmland grabbing in the EU. 2015. http://www.europarl.europa.eu/RegData/etudes/STUD/2015/540369/IPOL_STU(2015) 540369_EN.pdf.

[10] Lazić M. System and its Failure: Breakdown of Socialism and the Structures of the Yugoslav Society. Beograd; 1994 (In Serbian).

[11] Lazić M. Waiting for Capitalism. Beograd; 2011 (In Serbian).

[12] Macours K., Swinnen J. Patterns of agrarian transition. Economic Development and Cultural Change. 2002; 50 (2).

[13] Martinez-Alier J., Temper L., Munguti S. et al. The many faces of land grabbing. Cases from Africa and Latin America. EJOLT Report No. 10. 2014. http://www.ejolt.org/wordpress/wpcontent/uploads/2014/03/140305_EJOLT10.pdf.

[14] Mathijs E., Swinnen J. The economics of agricultural decollectivization in East Central Europe and the former Soviet Union. Economic Development and Cultural Change. $1998 ; 47$ (1).

[15] Nedelković M. Characteristics of the privatization of social agricultural enterprises. Agroekonomika. 2019 (In print) (In Serbian).

[16] Ploeg van der J., Franco J., Borras Jr.S. Land concentration and land grabbing in Europe: A preliminary analysis. Canadian Journal of Development Studies. 2015; 36 (2).

[17] Popov J. Drama in Vojvodina Village (1945-1952). Novi Sad; 2002 (In Serbian).

[18] Šljukić S., Janković D. Village in the Sociological Mirror. Novi Sad; 2015 (In Serbian).

[19] Šljukić S. Agriculture and the changes of the social structure: The case of Serbia. Sociologija. 2006; 48 (2).

[20] Šljukić S. Peasant and Cooperatives in the Plain. Novi Sad; 2009 (In Serbian). 
[21] Šljukić S. Sociological aspects of peasant cooperation in post-socialist Romania. New Europe College Regional Program Yearbook 2001-2002. Ed. by I. Vainovski-Mihai. Bucharest; 2002.

[22] Šljukić S., Šljukić M. Land and People. Novi Sad; 2012 (In Serbian).

[23] Spoor M. Agrarian reform and transition: What can we learn from "the East"? Journal of Peasant Studies. 2012; 39 (1).

[24] Stark D. Recombinant property in Eastern European capitalism. American Journal of Sociology. 1996; 101 (4).

[25] Stark D., Bruszt L. One way or multiple paths for a comparative sociology of East European capitalism. American Journal of Sociology. 2001; 106: (4).

\title{
Социологические аспекты трансформации аграрной структуры Сербии в 1990-2018 годы*
}

\author{
С. Шлюкич, М. Шлюкич \\ Университет Нови-Сада \\ ул. доктора Зорана Джинджича, 2, Нови-Сад, Сербия, 21000 \\ (e-mail: srdjan.sljukic@ff.uns.ac.rs).
}

\begin{abstract}
Один из конститутивных элементов прежних социалистических систем, который претерпел радикальные трансформации в последние десятилетия постсоциалистического транзита, - несомненно, аграрная структура. Авторы фокусируются на социологических аспектах трансформации аграрной структуры сербского общества с периода распада социалистической системы до сегодняшнего дня. Первая фаза трансформаций (1990-2000) создала социальную среду и предпосылки для запуска процесса дифференциации крестьянства, который продолжается по сей день. Вторая фаза (2001-2012) характеризуется появлением крупных сельскохозяйственных предприятий вследствие, прежде всего, процесса приватизации. На третьей фазе (с 2013 года по настоящее время) Сербия оказалась втянута в глобальный процесс «земельных захватов». Авторы утверждают, что в сельском хозяйстве вместо среднего класса, состоящего из фермеров, страна получила социально дифференцированное крестьянство, противостоящее крупным хозяйственным формам. Эта ситуация типична для постсоциалистических государств по трем взаимосвязанным причинам: новый социально-экономический порядок был выстроен не на руинах, а из руин социализма; различные социальные акторы внутри сербского общества преследовали собственные интересы и в ходе перемен предпочли демогогически-декларативные инструкции внешних экспертов, особенно западных; новые политические элиты не пытались выстроить постсоциалистические государства по собственной модели, а старались удовлетворить запросы и реализовать планы своих правительств и бизнеса, т.е. в итоге термин «транзит» следует заменить на понятие «периферизация». В заключительной части статьи авторы пытаются ответить на вопрос, почему ожидания относительно результатов транзита в сельском хозяйстве не оправдались и почему институциональные условия для большинства фермеров, работающих в хозяйствах среднего размера, не были созданы. Также авторы пробуют предугадать возможные будущие изменения в аграрной структуре Республики Сербия.
\end{abstract}

Ключевые слова: аграрная структура; крупные сельскохозяйственные угодья; земельные захваты; Сербия; крестьянство; фермеры; транзит

* C С. Шлюкич, М. Шлюкич, 2019.

Статья поступила в редакијию 31.01.2019. 